\title{
POTRET BUDAYA ORGANISASI MA AL-AMIRIYYAH BLOKAGUNG TEGALSARI BANYUWANGI
}

\author{
Siti Aimah \\ aimahabdullah12413@gmail.com \\ Institut Agama Islam Darussalam Bloagung, Indonesia
}

\begin{abstract}
ABSTRAK
Setiap lembaga pendidikan Islam perlu memiliki desain organisasi yang didasarkan pada visi, misi, nilai-nilai, asumsi-asumsi dan tujuantujuan yang telah ditetapkan. Filosofi dan asumsi-asumsi tersebut dikenal dengan budaya organisasi. Budaya organisai diperlukan untuk mengubah perilaku individual menjadi perilaku organisasional. Karena itu, akan dipaparkan tentang: (1) Makna Dari Budaya Organisasi; (2) Tingkatan Budaya Organisasi; (3) Bagaimana Budaya Organisasi Dimulai (4) Peran Budaya Organisasi; (5) Implementasi Budaya Organisasi; (6) Membangun Budaya yang Kuat Pada Organisasi (7) Mengenali Lingkungan dan Proses Adaptasi; (8) Budaya Organisasi di Madrasah Aliyah Amiriyyah Blokagung Tegalsari Banyuwangi; (9) Peran Pimpinan dalam Sosialisasi dan Implementasi Budaya Organisasi di MA al-Amiriyyah Blokagung Tegalsari Banyuwangi. Secara sederhana penelitian ini dapat disimpulkan bahwa budaya organisasi didefinisikan sebagai seperangkat asumsi yang dibangun dan dianut bersama oleh organisasi sebagai moral dalam beradaptasi dengan lingkungan eksternal dan proses integrasi internal.

Diantranya proses organisasi, artifak; nilai-nilai; dan asumsi dasar yang dipengarauhi oleh para pendiri organisasi secara tradisional. Budaya organisasi yang ada di Madrasah Aliyah al-Amiriyyah Blokagung dibagi menjadi tiga ranah, yaitu: (1). Budaya Keagamaan kegiatan pesantren; (2) Budaya Keindonesiaan, (3) Budaya Kemanusiaan. Hal ini juga didukung dengan peran pimpinan dalam sosialisasi dan implementasi budaya organisasi di Madrasah Aliyah al-Amiriyyah dilakukan secara tertulis dan tidak tertulis.
\end{abstract}

Kata Kunci : Pendidikan Islam, Organisasi, Pendidikan Global 


\section{Pendahuluan}

Lembaga Pendidikan apapun jenisnya adalah organisasi yaitu unit sosial yang terdiri dari orang-orang yang berinteraksi untuk mencapai tujuan yang telah ditetapkan. Organisasi hidup dalam sebuah sistem sosial yang saling mempengaruhi dan menimbulkan sebuah lingkungan baru yang kompleks, karena kepentingan masing-masing. Sebagai unit sosial organisasi terdiri dari orang-orang yang memiliki latar belakang sosial, ekonomi, budaya, motivasi dan pengalaman yang berbeda. Hal inilah yang akan mempengaruhi perilaku individual dalam sistem keorganisasian dan mengganggu kinerja organisasi, baik dalam beradaptasi dengan lingkungan eksternal maupun internal. Konsekuensinya, setiap lembaga pendidikan Islam perlu memiliki desain organisasi yang didasarkan pada visi, misi, nilai-nilai, asumsi-asumsi dan tujuan-tujuan yang telah ditetapkan. Filosofi dan asumsi-asumsi tersebut dikenal dengan budaya organisasi.

Budaya organisai diperlukan untuk mengubah perilaku individual menjadi perilaku organisasional. Budaya organisasi diciptakan oleh para pendiri organisasi. Implementasi budaya organisasi dipelopori oleh para pendiri dan para pimpinan organisasi untuk memberi keteladanan pada anggota organisasi. Lebih lanjut disebutkan bahwa budaya organisasi merupakan moral yang mengarahkan perilaku organisasional secara bertanggungjawab dan membangun citra positif organisasi. Dalam istilah lain budaya organisasi disebut sebagai jiwa yang dapat menjadi identitas organisasi terkait.

Sementara itu sosialisasi budaya diperlukan dalam sebuah proses yang menggunakan seperangkat alat agar filosofi dan asumsi-asumsi yang telah dibangun dapat difahami serta diimplementasikan dalam kehidupan dan keberlangsungan organisasi. Dan unsur yang paling bernilai dalam 
budaya organisasi adalah keteladanan para pemimpin, termasuk pendiri organisasi. Unsur lainnya adalah penokohan, rutinitas, simbul dan slogan.

Selanjutnya, interaksi orang-orang-orang dalam sebuah organisasi dilandasi nilai-nilai yang mereka ciptakan dan dianut bersama adalah implementasi dari budaya organisasi. Pada tatanan kehidupan jangka panjang sebuah organisasi, kepentingan individu dan organisasi sering menjadi konflik yang dilematis. Konflik kepentingan antar individu dan organisasi merupakan dilema etika, yaitu suatu situasi dimana setiap pilihan keputusan atau perilaku berpotensi menimbulkan reaksi. Individu, baik pengelola organisasi maupun pegawai organisasi harus memahami etika yaitu aturan mengenai nilai-nilai moral yang mengatur perilaku seseorang atau kelompok organisasi dalamkaitan dengan nilai baik dan buruk. Etika organisasi berkaitan dengan nilai-nilai internal yang dikembangkan dalam budaya organisasi dan berhubungan dengan tanggungjawab sosial.

Sementara itu kunci sukses penyelesaian konflik kepentingan adalah pendekatan moral dan hak-hak individu. Pendekatan moral adalah keputusan-keputusan organisasi yang tidak melanggar hak asasi individu, baik mereka sebagai pegawai, anggota masyarakat maupun pelanggan yang menyangkut hak-hak kebebasan pribadi; mengungkapkan pendapat, kesejahteraan dan partisipasi dalam turut serta mengembangkan organisasi.

Menilik paparan diatas maka penelitian ini akan membahas tentang: (1) Makna Dari Budaya Organisasi; (2) Tingkatan Budaya Organisasi; (3) Bagaimana Budaya Organisasi Dimulai (4) Peran Budaya Organisasi; (5) Implementasi Budaya Organisasi; (6) Membangun Budaya yang Kuat Pada Organisasi (7) Mengenali Lingkungan dan Proses Adaptasi; (8) Budaya Organisasi di Madrasah Aliyah Amiriyyah Blokagung Tegalsari 
Banyuwangi; (9) Peran Pimpinan dalam Sosialisasi dan Implementasi Budaya Organisasi di MA al-Amiriyyah Blokagung Tegalsari Banyuwangi.

\section{Memahami Makna Budaya Organisasi}

Organisasi terdiri dari orang-orang yang memiliki latar belakang beragam yang mungkin berbeda dengan nilai-nilai organisasi. Oleh karenanya organisasi perlu menciptakan seperangkat asumsi dasar atau budaya yang menjadi basis dalam mengubah perilaku individual menjadi perilaku organisasional. Budaya organisasi telah didefinisikan oleh banyak ahli baik dari kalangan manajemen, sosial, antropologi, maupun organisasi diantaranya: (1) memaparkan bahwa budaya organisasi adalah seperangkat asumsi dasar yang diciptakan, ditemukan atau dikembangkan dan dianut bersama sebagai pembelajaran untuk mengatasi masalahmasalah adaptasi dengan lingkungan eksternal dan integrasi internal. (Schein, 1989). (2) menjelaskan tentang budaya organisasi sebagai filosofi, ideologi, nilai-nilai, keyakinan, asumsi-asumsi dan norma-norma yang dianut bersama, lebih lanjut Kilmann menyebut bahwa budaya organisasi adalah kekuatan yang tidak tampak di balik sesuatu yang nyata dan dapat diamati diberbagai organisasi, sebagai energi sosial yang mengarahkan manusia dalam bertindak. (Kilmann, 1988). (3) Menguraikan budaya organisasi sebagai suatu persepsi bersama yang dianut oleh anggotaanggota organisai itu, yakni suatu sistem dari makna bersama. (Robbins, 1998).

Berkaitan dengan sistem makna menyatakan bahwa budaya adalah "software of mind" yang menjadi mental programming organisasi dalam mengarahkan pola-pola berfikir, merasakan dan tindakan organisasional. Berangkat dari berbagai pengertian tentang budaya organisasi di atas, dapat difahami bahwa budaya organisasi adalah sistem makna untuk membina mental agar pemikiran dan tindakan individu organisasi 
didasarkan pada pertimbangan moraldan dapat dipertanggungjawabkan. (Hofstede, 1991). Oleh karena itulah secara sederhana budaya organisasi didefinisikan dalam penjelasan lain, sebagai seperangkat asumsi yang dibangun dan dianut bersama oleh organisasi sebagai moral dalam beradaptasi dengan lingkungan eksternal dan proses integrasi internal.

\section{Tingkatan Budaya Organisasi}

Lebih luas tentang isi budaya organisasi. Menurutnya terdapat tiga tingkatan budaya organisasi yang berinteraksi dalam proses keorganisasian yaitu artifak; nilai-nilai; dan asumsi dasar. (Schein, 1997). Ketiganya diilustrasikan dalam gambar berikut:

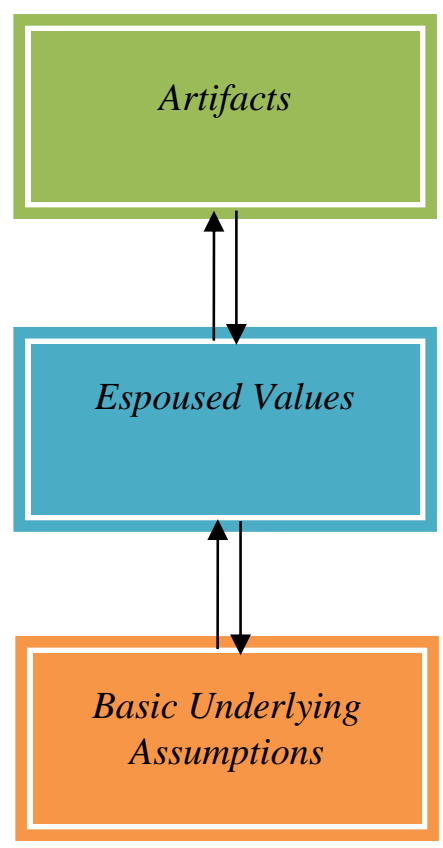

Visible organizational structures and processes (hard to decipher)

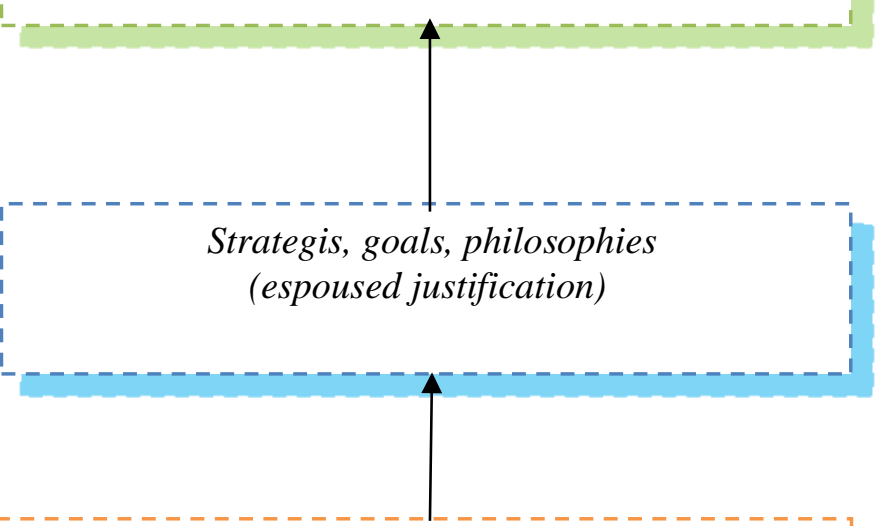

Unconscious, takemn-for-granted belief, perceptions, thoughts and feelings (ultimate source of values and action)

Gambar 1. Tingkat-tingkat dari budaya Sumber: (Schein, 1997)

Artifacts adalah produk-produk nyata dari kelompok seperti arsitektur lingkungan fisik, bahasa , teknologi, kreasi artistik, tata ruang, cara berpakaian, cara berbicara, cara mengungkapkan perasaaan, cerita 
tentang mitos dan sejarah organisasi, daftar nilai-nilai yang dipublikasikan, kegiatan ritual dan seremonial serta perilaku. Untuk tujuan analisis tingkatan tersebut termasuk perilaku yang tampak dari kelompok dan proses keorganisasian yang dilakukan secara rutin.

Values adalah adalah apa yang secara ideal menjadi alasan untuk berperilaku. Nilai-nilai merupakan sesuatu yang berharga untuk difahami, dan dikerjakan sebagai landasan komitmen organisasi. Nilai-nilai biasanya ditemukan oleh para pendiri organisasi seperti strategi-strategi, tujuantujuanm filosofi serta pencapaian tujuan-tujuan. Bentuk nyata dari nilainilai dapat berupa: filosofi; visi; disiplin kerja; sistem balas jasa; cara berinteraksi.

Basic Underlying Assumptions adalah apa yang tidak disadari, tetapi secara aktual menetukan bagaimana anggota organisasi mengamati, berfikir, merasakan dan bertindak. Budaya menetapkan cara yang tepat bagi organisasi untuk melakukan sesuatu yang sesuai visi, misi dan tujuan yang ditetapkan. Keteladanan adalah cara atau pola komunikasi organisasi, baik internal maupun eksternal dan merupakan bagian dari tindakan nyata dari asumsi dasar.

Ketiga tingkatan isi budaya itu dapat saling tumpang tindih, atau difahami sendiri-sendiri atau juga merupakan bagian integral dari sebuah organisasi. Pemahaman ketiga isi budaya tersebut tergantung dari filosofi pendiri, jenis kegiatan, ukuran besaran dan lingkungan organisasi. Contoh, PT Telkom memanifestasikan asumsi dasar sebagai komponen terdalam dalam budaya yang mereka jadikan motto - Commited $2 \mathcal{U}$. Sedangkan nilai dan perilaku merupakn manifestasi yang lebih konkrit dari asumsi dasar, dan artifak adalah sesuatu yang bisa dilihat dan dirasakan. Dengan kata lain, bahwa ketiga lapisan budaya tersebut merupakan kumpulan unsur yang terintegrasi dan harus difahami serta diimplementasikan sebagai satu kesatuan. 
Lebih lanjut Schein menjelaskan bahwa tiga lapisan isibudaya organisasi tdak cukup hanya dengan dilihat bagaimana sekelompok orang membangun kondisi lingkungannya, tetapi juga perlu ditelusuri dengan adanya "the underlying logic", yaitu mengapa suatu kelompok berfikir dan bertindak dengan cara tertentu yang mereka temukan. Kelompok orang yang dimaksud adalah anggota suatu organisasi tempat kelompok tersebut berinteraksi untuk mencapai tujuan tertentu.

\section{Bagaimana Budaya Organisasi Dimulai}

Setiap dimulainya kegiatan dari sebuah organisasi, maka perlu menetapkan sejumlah filosofi, aturan, tujuan-tujuan dan sistem keorganisasian yang dibangun oleh para penggagas, pendiri dan pemilik organisasi. Filosofi dan lainnya tersebut merupakan asumsi dasar yang dijadikan perilaku organisasional yang pada perkembangannya menjadi budaya organisasi. Kebiasaan dewasa ini, tradisi dan cara umum organisasi dalam melakukan segala tindakan, sebagian besar disebabkan oleh apa yang telah dilakukan sebelumnya, dan tingkat keberhasilan diperoleh melalui kerja keras. Hal tersebut mengarahkan kita pada pemikiran bahwa sumber paling akhir dari budaya organisasi adalah pendirinya. (Schein, 1983).

Pendiri organisasi yang biasanya juga menjadi pemilik akan mempengaruhi pola pengelolaan usaha. Ide-ide, nilai-nilai muncul dari pemikiran para pendiri dan pemilik. Para pendiri suatu organisasi secara tradisional mempunyai dampak utama pada permulaan budaya organisasi. Mereka mempunyai suatu visi mengenai bagaimana seharusnya organisasi beroperasi. (Robbins, 1998).

Adalah sesuatu yang sangat sulit untuk digeneralisasikan bagaimana budaya organisasi dimulai, sebab banyak organisasi memiliki jenis kegiatan dan lingkungan yang sama, tetapi memiliki budaya yang berbeda. 
Hal ini disebabkan karena latar belakang sosial budaya pendiri organisasi berbeda dalam filosofi dan visinya. Pada dasarnya budaya muncul dari tiga sumber: (1) keyakinan-keyakinan, nilai-nilai, dan asumsi para pendiri organisasi; (2) belajar dari pengalaman yang dilakukan oleh anggota kelompok sebagaimana perkembangan organisasi; (3) keyakinan, nilai-nilai dan asumsi-asumsi baru yang dibawa masuk oleh pimpinan dan anggota baru. (Schein, 1997).

\section{Peran budaya organisasi}

Budaya mempunyai kaitan dan peran terhadap berbagai aspek kehidupan organisasi secara menyeluruh. Secara spesifik budaya memiliki lima peran: (1) budaya memiliki rasa identitas dan kebanggaan, yaitu menciptakan perbedaan yang jelas antar organisasi satu dengan yang lain; (2) budaya mempermudah terbentuknya komitmen dan pemikiran yang lebih luas daripada kepentingan pribadi seseorang; (3) memperkuat strandar perilaku organisasi dalam membangun pelayanan superior pada pelanggan; (4) budaya menciptakan pola adaptasi; (5) membangun sistem kontrol organisasi secara menyeluruh. (Schein, 1997).

Budaya dalam proses keorganisasian menjadi dasar dari desain organisasi yang mencakup tujuan, struktur, teknologi dan pola pengelolaan. Dalam proses keorganisasian, perilaku organisasi yang didasari oleh budaya, berkaitan dengan tingkat produktifitas dan kepuasan kerja anggita organisasi. Produktifitas dan kepuasan kerja mendorong timbulnya rasa memiliki organisasi. Secara ringkas budaya dan proses keorganisasian dideskripsikan pada gambar berikut: 


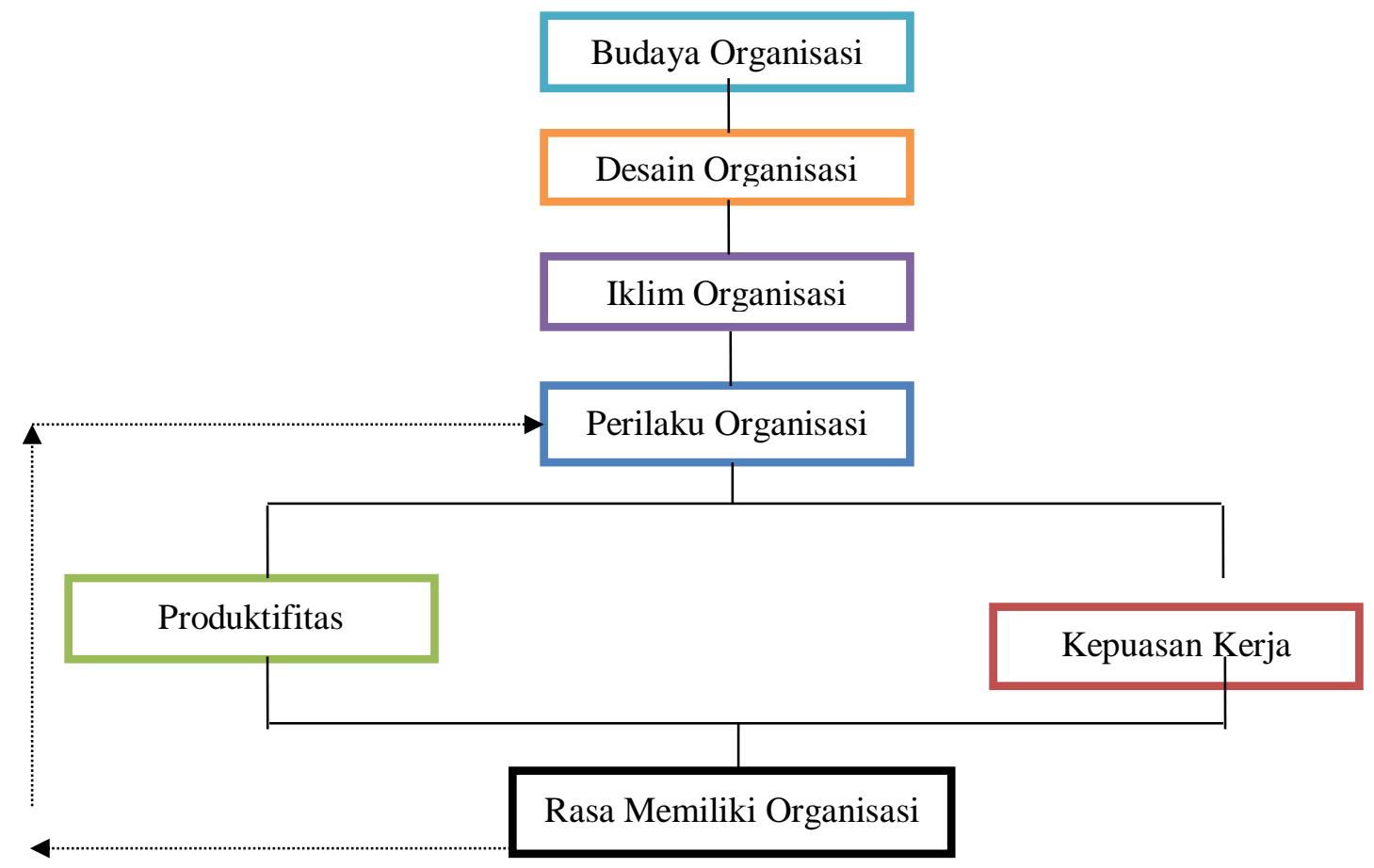

Gambar 2. Budaya dalam Proses Keorganisasian Sumber: (Schein,1997)

\section{Implementasi Budaya Organisasi}

Implementasi budaya adalah sebuah proses yang terintegrasi dalam sebuah simbol sosial, yang merupakan sosialisasi. Sosialisasi merupakan proses adaptasi anggota organisasi terhadap budaya yang diciptakan oleh organisasi. Sosialisasi budaya terdiri dari dua tahap pokok; pembelajaran dan adaptasi. Tahap pembelajaran adalah waktu dimana anggota organisasi belajar tentang pola kehidupan organisasi. Anggota organisasi mempelajari berbagai aturan yang berkaitan dengan pelaksanaan tugas serta pola perilaku organisasional. (Robins, 1998).

Tahap adaptasi merupakan waktu dimana anggota organisasi sudah melakukan penyesuaian terhadap sistem keorganisasian yang merupakan sebuah proses. Proses adaptasi anggota organisasi berjalan melalui 
berbagai cara: keteladanan dari para pemimpin; penokohan, yaitu cerita tentang para pendahulu dalam membesarkan organisasi; rutinitas; simbolis dan slogan atau kredo.

Keteladanan adalah tindakan dan pemikiran-pemikiran seseorang dalam mengimplementasikan sesuatu yang telah menjadi keharusan secara benar, yang dapat ditiru atau menjadi model-model peran nyata bagi anggota organisasi. Para pemimpin puncak organisasi terutama pendiri yang menciptakan filosofi merupakan sumber-sumber kekuatan dalam sosialisasi budaya. Perilaku individual para pemimpin baik dalam kehidupan sehari-hari maupun organisasi merupakan suri tauladan bagi anggota organisasi.

Dalam keteladanan membutuhkan adanya penokohan, rutinitas, simbol dan slogan. Seperti halnya diketahui bersama, cerita tentang tokoh adalah bagian dari kehidupan manusia dan mempunyai makna serta manfaat bagi masa depan baik secara individu maupun organisasi. Cerita adalah tradisi yang merupakan salah satu alat komunikasi untuk menyampaikan nilai-nilai, tata cara, anggapan maupun prestasi dari waktu ke waktu dan merupakan bagian dari proses cadre forming yang bertujuan untuk memberi pelajaran bagi generasi penerus dalam mengendalikan dinamika organisasi. Seperti juga legenda lain, cerita tentang warisan organisasi memiliki tujuan: (1) menanamkan nilai-nilai organisasi; (2) keteladanan; (3) petunjuk dalam melaksanakan suatu pekerjaan sesuai dengan budaya organisasi; (4) mendorong perubahan; (5) pengendali organisasi.

Sedangkan rutinitas dalam organisasi dapat dilakukan dengan dua cara, yaitu melalui sturktur dan non struktur. Struktur organisasi membakukan komunikasi organisasi yang menunjukkan tentang bagaimana tugas pekerjaan dibagi, dikelompokkan dan dikordinasikan secara formal. Sementara itu non struktur adalah kegiatan-kegiatan sosial 
organisasi yang dilakukan dengan pembentukan identitas dan kebanggaan.

Setiap organisasi mempunyai enam bagian dasar yaitu: (1) Ideology (yang sekarang populer dengan istilah budaya) meliputi tradisi dan keyakinan-keyakinan organisasi yang membedakan dengan organisasi lain dan menanamkan kehidupan yang pasti ke dalam kerangka struktur; (2) Strategic Apexmanager puncak yang diberi kekuasaan untuk menjalankan misi dan kontrol organisasi secara efektif; (3) Middle Linepara manajer yang menjadi penghubung kelompok operating core dengan strategic apex; (4) The Technostructureanalisis kontrol dari organisasi untuk menjalankan bentuk standarisasi tertentu atau khusus di dalam organisasi; (5) The Support Staffadalah orang-orang yang berada pada sejumlah unit organisasi, semua spesialis yang tugasnya memberikan dukungan tidak langsung; (6) The Operating Core meliputi anggota-anggota, para operator, mereka yang pekerjaan dasarnya berhubungan langsung dengan produksi, baik barang maupun jasa. (Mintzberg, 1989).

Selanjutnya simbol adalah objek atau tindakan yang memberi arti bagi perusahaan dapat berupa logo, materi atu tindakan yang di dalamnya mengandung filosofi. Dan slogan atau yang sering disebut kredo adalah kata-kata atau kalimat yang mengekspresikan suatu nilai bagi organisasi secara singkat dan mempunyai makna khusus bagi organisasi secara keseluruhan.

Dengan demikian sosialisasi budaya merupakan proses melalui beberapa tahapan, waktu, dan kontrol yang ketat, karena angota organisasi memiliki latarbelakang yang berbeda dan menyebabkan persepsi mereka terhadap keinginan organisasi menjadi berbeda pula. Maka hal inilah yang pada perkembangan selanjutnya menjadi dasar atas lahirnya perilaku organisasi. Untuk lebih mudah dalam memahaminya, perhatikan gambar berikut. 


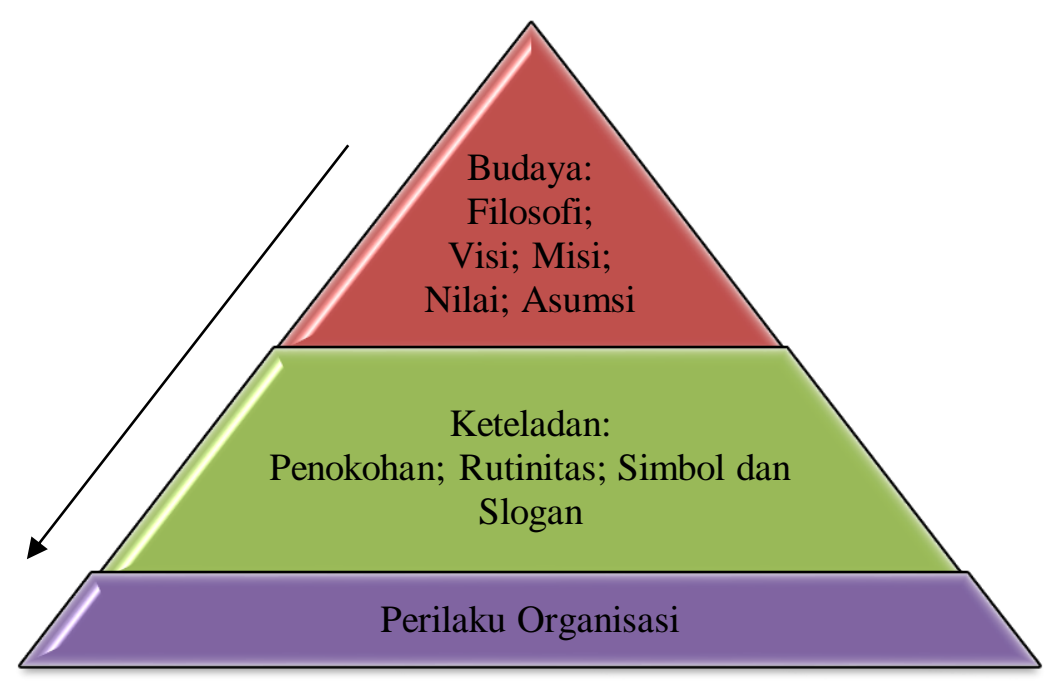

Gambar 3. Sosialisasi Budaya dan Eksistensi Organisasi Sumber: (Robins, 1998).

\section{Membangun Budaya yang Kuat}

Budaya akan membentuk karakteristik serta membangun kepercayaan organisasi. Terdapat tiga langkah dalam mendorong budaya yang sukses yaitu: komitmen, kompetensi dan konsistensi atau 3K. (Hickman dan Silva, 1984). Komitmen adalah perjanjian anggota organisasi terhadap eksistensi organisasi. Kompetensi merupakan kemampuan untuk melaksanakan tugas-tugas dalam rangka mencapai tujuan-tujuan organisasi, dan konsistensi ialah kemantapan untuk secara terus menerus berpegang pada komitmen dan kemapuannya sebagai anggota organisasi yang bertanggungjawab terhadap kelangsungan organisasi.

Sementara itu studi lain menemukan bahwa budaya yang kuat dibangun oleh empat dimensi $\mathrm{K}$ yaitu: komitmen; kemampuan; kepaduan/kohesi; dan konsistensi. (Poerwanto, 1992). Komitmen untuk melakukan yang terbaik bagi organisasi perlu didukung oleh kemampuan individual, baik keahlian tenis, psikologis amaupun sosiologis, yang tujuannya untuk memadukan diri sebagai bagian dari kehidupan 
organisasi secara menyeluruh. Kondisi tersebut harus dilaksanakan secar konsisten terhadap apa yang telah disepakati bersama. Keempat $\mathrm{K}$ pembentuk budaya yang kuat tersebut merupakan satu kesatuan yang tidak dapat dipisah-pisahkan sesuai dengan gambar berikut.

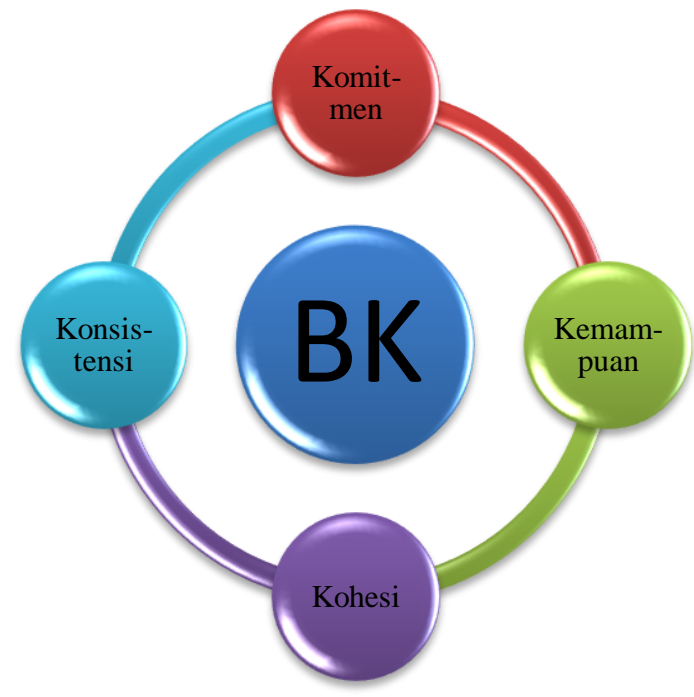

Gambar 4. Empat Dimensi K Pembentuk Budaya yang Kuat (BK) Sumber: (Poerwanto, 1992, 2004)

\section{Mengenali Lingkungan dan Proses Adaptasi pada Organisasi}

Lembaga Pendidikan Islam sebagai organisasi merupakan sebuah sistem terbuka yang berada di suatu lingkungan. Lingkungan organisasi disini definisikan sebagai semua elemen baik yang berada di dalam maupun di luar organisasi yang mempunyai potensi untuk mempengaruhi organisasi. Sebuah pengaruh besar pada budaya internal organisasi adalah lingkungan eksternal. Budaya dapat sangat beragam pada setiap organisasi, nilai-nilai yang telah diciptakan dan dianut bersama harus menjadi inti pembuatan kebijakan manajerial. (Chaitman dan Karen, 1994).

Lingkungan dalam atau internal dapat difahami sebagai lingkungan yang langsung dapat mempengaruhi kinerja organisasi. Lingkungan 
internal organisasi tergolong ke dalam lingkungan yang dapat dikendalikan. Sebaliknya, lingkungan luar atau eksternal merupakan lingkungan yang tidak secara langsung dapat mempengaruhi organisasi dan dikategorikan sebagai lingkungan yang sulit dikendalikan. Elemenelemen lingkungan luar terdiri dari pesaing, swasta, pemerintah dan masyarakat.

Sebagai sistem terbuka, lembaga pendidikan Islam sebagai organisasi perlu membangun strategi pengendalian sebagai bagian dari kehidupan yang berkaitan dengan lingkungannya. Setiap organisasi harus mengembangkan konsep adaptasi secara menyeluruh sebagai tugas mengendalikan lingkungan ynag sesuai visi; misi; tujuan-tujuan; kemampuan dan jenis kegiatan. Budaya organisai sebagai jiwa merupakan filter bagi manajemen dalam mengadaptasi elemen-elemen lingkungan, sekalipun dalam proses adaptasi dimungkinkan budaya dapat ikut berubah.

Tugas inti lembaga pendidikan Islam sebagai organisasi dalam menghadapi lingkungan adalah berdaptasi. Adaptasi adalah dari sistem organisasi untuk menyesuaikan terhadap lingkungannya dengan mendayagunakan potensi sumber daya yang dimiliki.kemampuan adaptasi merujuk pada banyaknya sumber daya serta kecakapan yang dimilki untuk mengelola kelangsungan hidup organisasi dalam lingkungannya.

Kenyataan menunjukkan bahwa setiap organisasi harus beradaptasi dengan lingkungannya. Organisasi harus melakukan adaptasi dalam kaitan dengan kelangsungan hidup untuk menjadi lebih baik, khususnya terhadap perubahan yang cepat dan terus menerus. Adaptasi juga berarti reaksi dan merupakan proses penyesuaian dalam rangka memperbaiki organisasi terhadap berbagai tuntutan lingkungan. (Espejo, 1996). 
Perubahan organisasi dapat diilhami dari berbagai kondisi eksternal maupun internal organisasi. Demikian halnya dengan lembaga pendidikan Islam, seluruh anggotanya di semua tingkatan perlu untuk diberi kesempatan dalam mengembangkan kemampuannya dan mencari bentuk perubahan yang sesuai dengan kebutuhan dan kemampuan organisasi. Adaptasi juga merupakan bagian dari proses perubahan dalam setiap kehidupan organisasi. Selain itu adaptasi juga berkaitan dengan perubahan internal yang mencakup penyesuaian pada sistem, struktur, pola kerja dan aspek internal lainnya terhadap karakteristik lingkungan yang dihadapi. Perubahan karena adaptasi dengan lingkungan dapat mendorong perubahan budaya organisasi.

\section{Budaya Organisasi di Madrasah Aliyah al-Amiriyyah Blokagung}

Madrasah Aliyah al-Amiriyyah Blokagung merupakan salah satu unit lembaga pendidikan Islam yang bernaung pada yayasan pesantren Darussalam Blokagung Tegalsari Banyuwangi, bersifat formal dan berada pada tingkat Sekolah Menengah Tingkat Atas (SLTA) dikenal sebagai sekolah/madrasah berbasis pesantren. Hal ini berdasar pada integrasi yang dibangun kuat antara pihak pesantren sebagai pemrakarsa yang secara legal formal dan moral pada kelangsungan kegiatan pendidikan serta pihak Madrasah Aliyah al-Amiriyyah yang secara struktural menjadi pengelola kegiatan pendidikan yang diselenggarakan. Sehingga keterpaduan antara teori yang diterima peserta didik di madrasah bisa diterapkan secara langsung di kehidupan pesantren, dan sebaliknya. Ada tiga budaya yang sudah diterapkan di Madrasah Aliyah (MA) al-Amiriyyah Blokagung dalam mengembangkan statusnya sebagai lembaga pendidikan Islam berbasis pesantren, yaitu: 


\section{Budaya Keagamaan}

a. Mukim di Pesantren

Tidak seperti unit pendidikan tingkat SLTA lainnya yang bernaung pada yayasan pesantren Darusalam Blokagung, yakni SMA dan SMK Darussalam Blokagung yang berafiliasi pada kementerian pendidikan nasional dan kebudayaan, MA al-Amiriyyah Blokagung berafiliasi pada kementerian agama Republik Indonesia, maka semakin menegaskan bahwa MA al-Amiriyyah Blokagung lebih religius sebagai lembaga pendidikan berbasis pesantren dengan mewajibkan peserta didiknya baik putra maupun putri untuk mukim di pesantren. Hal ini tidak terjadi pada SMA dan SMK Darusalam Blokagung. Karena dengan mukim di pesantren secara wajib itulah yang menyebabkan kepribadian peserta didik bermoral mulia akan bisa terwujud nyata, melalui kegiatan pendampingan dan pembinaan oleh pengasuh, pengurus dan ustadz/ustadzah pesantren, diantaranya dengan keteladan, pembiasaan (rutinitas) kegiatan pesantren dan pendidikan diniyah (agama).

b. Membaca asma'ul husna sebelum memasuki kelas

Pembacaan asma'ul husna ini dilakukan secara serentak di halaman madrasah dan dipimpin oleh imam yang ditunjuk secara bergilir oleh pimpinan madrasah. Maka 15 menit sebelum bel masuk jam pertama kegiatan ini rutin dilakukan dengan tujuan membiasakan kedisiplinan baik kepada ustadz/ustadzah maupun peserta didiknya, selain dengan tujuan utama yaitu memohon kepada allah swt untuk merahmati dan memberkahi pada proses kegiatan pendidikan yang dilaksanakan dengan menyebut asma-asmaNya yang Agung. 
c. Membaca doa sebelum dan sesudah pelajaran

Doa sebelum dan sesudah pelajaran ini merupakan ijasah yang disampaikan oleh pendiri pesantren, yakni almarhum al-Maghfurlah KH Mukhtar Syafa'at Abdul Ghofur sebagai wasilah untuk kelancaran pemahaman dan penguasaan peserta didik pada mata pelajaran yang diajarkan. Pembacaan doa ini biasanya dipimpin oleh Ustadz/Ustadzah yang masuk di jam pertama dan jam terakhir d. Menghafal al-Qur'an bagi peserta didik jurusan Agama

Kegiatan menghafal al-Qur'an ini diwajibkan bagipeserta didik yang mengambil jurusan agama dengan target satu tahun bisa mengahafal 10 jus al-Qur'an, sehingga 3 tahun bisa menyelesaikan khatam al-Qur'an 30 jus. Kegiatan ini didukung dengan memberikan asrama khusus bagai mereka dan melaksanakan istima'ul Qur'an setiap hari selasa, selain setoran al-Qur'an dan Tadarus al-Qur'an yang diselenggarakan pada pagi hari dan sore hari yang langsung dihadapan Kyai/Nyai, pengasuh pendidikan al-Qur'an di pesantren.

e. Mengadakan kegiatan PHBI (Peringatan Hari Besar Islam)

PHBI seperti peringatan maulid nabi Muhammad saw, isra' mi'raj, nuzulul Qu'an, Halal bi Halal, tahun baru Islam dan seterusnya dilaksanakan untuk mengambil hikmah dari setiap momentum agar keimanan dan ketaqwaan ustadz/ustadzah dan peserta didik bisa terus bertambah. Kegiatan tersebut biasanya dilaksanakan dengan cara sederhana berkumpul di halaman madrasah tanpa menggunakan tarup hanya dengan menggelar tikar seadanya, menghadirkan penceramah dari Ustadz/Ustadzah pesantren akan tetapi kekhidmatan acara tetaap terjaga. 
f. Menggelar dan mengikuti festival keagamaan Islam

Festival atau lomba keagamaan Islam dilaksanakan sebagai pembangun semangat prestasi dalam keagamaan secara rutin dilaksanakan setiap akhir semester. Sedangkan mengikuti lomba keagamaan dilakukan baik tingkat lokal maupun nasional, diantara prestasinya adalah sebagai juara 1 lomba Syarkhil Qur'an tingkat Jawa, Madura dan Bali, juara 1 tingkat Jawa Timur lomba membaca kitab salaf dengan hadiah umroh, Juara I Lomba menghafal alQur'antingkat nasional dan mendapat hadiah Ibadah Haji dan sebagai tamu kehormatan Kerajaan Arab Saudi

g. Silaturrahim kepada Kyai/Nyai dan Ustadz/Ustadzah

Pada waktu hari raya fitri dan adha silaturrahim kepada Kyai/Nyai dan Ustadz/Ustadzah sebagai bagian dari melestarikan tradisi Islam dan ngalap barokah(mengharap keberkahan ilmu) dari Kyai/Nyai dan Ustadz/Ustadzah yang telah berperan sebagai pendidik, pembimbing dan pendamping selama proses pendidikan Islam yang berorientasi pada pembangunan akhlak mulia peserta didik berlangsung di pesantren dan madrasah

h. Melaksanakan khotmil Qur'an dan istighatsah secara rutin dan berkala

Khotmil Qur'an dan istighatsah biasanya dilaksanakan menjelang pelasanaan ujian tingkat madrasah maupun nasional. Harapannya jelas sebagai doa kepada allah swt untuk melancarkan dan mensukseskan kegiatan ujian tersebut, sehingga hasilnya bisa memuaskan kepada peserta didik, orang tua, madrasah dan pesantren.

i. Mengikuti kegiatan pesantren dan pendidikan diniyah

Kegiatan pesantren, baik berupa pengajian al-Qur'an maupun kitab salaf bertujuan untuk mendukung kegiatan diniyah (agama) 
yang dilangsungkan di Madrasah Diniyah al-Amiriyyah yang berafiliasi pada kementerian agama sebagai lembaga pendidikan non formal namun menjadi ruhnya pesantren. Dengan pemahaman tersebut, maka peserta didik MA al-Amiriyyah wajib mengikuti kegiatan-kegiatan tersebut sebagai bentuk konkrit dukungan kepada madrasah yang berorientasi pada pengembangan sekolah berbasis pesantren. Maka dengan penjelasan tersebut, peserta didik MA alAmiriyyah berstatus ganda sebagai peserta didik (santri) pendidikan diniyah dan pesantren. Akan tetapi alokasi waktunya dibuat jelas, pagi hari untuk kegiatan pendidikan di MA al-Amiriyyah, sore dan malam hari digunakan untuk kegiatan pesantren dan pendidikan diniyah, sehingga menghindarkan adanya tumpang tindih kegiatan pendidikan.

j. Ziarah ke makam para pendidiri pesantren

Ziarah ke makam (maqbarah) pendiri dilaksanakan pada hari libur madrasah yakni hari jum'at, kegiatan ini dilaksanakan dengan tujuan untuk mengenang jasa-jasa pendiri, serta yang utama mendoakan mereka yang juga dengan juga dengan tujuan wasilah (perantaraan) agar-agar doa-doa ustadz/ustadzah dan peserta didik dapat dikabulkan oleh allah swt.

\section{Budaya KeIndonesiaan}

a. Mengadakan Upacara setiap hari senin dan hari kemerdekaan Indonesia

Upacara juga merupakan kegiatan rutin yang dilaksanakan meskipun MA al-Amiriyyah notabene adalah sekolah swasta dan berorientasi agama serta berbasis pesantren. Karena dengan pelaksanaan upacara, ustadz/ustadzah dilatih disiplin dan mengenang serta mendoakan para pahlawan yang menjadikan negeri 
ini merdeka. Selain itu dengan pelaksanaan upacara semangat nasionalisme ustadz/ustadzah dan peserta didik terus dibangun, sehinggu ke depan semangat itulah yang diharapkan bisa memberikan kontribusi nyata untuk pembangunan Indonesia. Pelaksanaan upacara itu juga dengan mengikutsertakan peserta didik MA al-Amiriyyah pada upacara hari kemerdekaan Indonesia di tingkat kecamatan dan kabupaten.

b. Mengadakan kegiatan hari-hari nasional

Kegiatan hari-hari nasional diadakan untuk mewujudkan secara nyata sikap patriotisme ustadz/ustadzah dan peserta didik melalui deklarasi kembali Sumpah Pemuda, teatrikal kebangsaan saat peringatan hari pendidikan nasional, pembacaan puisi saat peringatan hari kartini, pertunjukkan drama kolosal perjuangan kemerdekaan saat peringatan hari kemerdekaan Indonesia dan sebagainya. Sehingga mereka akan terbiasa menjunjung tinggi nilainilai kebangsaan yang dicontohkan oleh para pejuang kemerdekaan dan melanjutkan estafetnya untuk membangun Indonesia menjadi negara yang Gemah Ripah Loh Jinawi seperti cita-cita mulia para pendiri bangsa Indonesia

\section{Budaya Kemanusiaan}

a. Melaksanakan kamis amal

Kegiatan kamis amal adalah kegiatan pengumpulan dana sedekah dari ustadz/ustadzah dan peserta didik ynag digunakan untuk membeli paket sembako dibagikan pada fakir miskin sekitar madrasah (pesantren) serta donasi untuk beasiswa pendidikan kepada peserta didik yang kurang mampu. Kegiatan ini biasanya secera serentak dilakukan di waktu menjelang jam istirahat dengan panitia khususnya yaitu pengurus osis dibantu pengurus kelas masing-masing 
b. Menggelar donor darah

Donor darah dilakukan setiap akhir semester bersamaan dengan kegiatan festival keagamaan bekerjasama dengan Palang Merah Indonesia (PMI) kabupaten Banyuwangi. Kegiatan ini berorientasi pada kebutuhan darah bagi pasien-pasien yang sangat membutuhkan sehingga keselamatan mereka bisa tertolong, berlatar fenomena semakin jarangnya orang yang secara sukarela dan berkala mau melaksanakan donor darah

c. Membantu teman dan masyarakat yang terkena musibah

Mengunjungi teman atau keluarganya yang sakit sudah terbiasa dilakukan oleh ustadz/ustadzah dan peserta didik MA al-Amiriyyah, disana selain mendoakan kesembuhannya juga memberikan sumbangan yang biasanya dikumpulkan sebelum berangkat. Hal ini menjadi lebih utama saat teman atau keluarganya ada yang meninggal dunia, maka biasnya mereka ikut dalam proses sholat janasah, pemakaman dan mebacakan yasin-tahlil serta sumbangan kifayah. Selain itu, jika ada musibah yang menimpa masyarakat sekitar maupun skala nasional ustadz/ustadzah dan peserta didik tergerak membantu mendoakan dan mengirimkan bantuan semampunya, mulai sembako dan pakaian ala kadarnya.

d. Bhakti sosial kemasyarakatan

Bhakti sosial dilakukan pada saat liburan panjang sekolah (madrasah) yang karena integrasi dengan pesantren juga menjadi libur panjang pesantren. Kegiatan yang dilaksanakan biasanya seputar pembinaan masyarakat buta huruf, pembagian gizi untuk mewujudkan masyarakat sehat bekerjasama dengan Puskesmas Tegalsari, pemberian jamban bagi masyarakat yang masih terbiasa membuang kotoran di sungai dan seterusnya. 
Peran Pimpinan dalam Sosialisasi dan Implementasi Budaya Organisasi di MA al-Amiriyyah Blokagung

Pimpinan yang dimaksud disini adalah pimpinan pesantren dan pimpinan (kepala) Madrasah Aliyah al-Amiriyyah, hal ini sebagai bukti dari integrasi yang terjadi antara pihak pesantren dan pihak madrasah. Hal ini disebabkan Madrasah Aliyah al-Amiriyyah yang bernaung pada yayasan pesantren Darussalam Blokagung ini, adalah salah satu unit pendidikan formal tingkat SLTA yang di bawah koordinasi langsung kepala bidang pendidikan dan pengajaran yayasan pesantren Darussalam Blokagung. Maka sebutan pimpinan kembali kepada pihak-pihak yang berkepentingan, yakni pesantren dan madrasah.

Sementara itu peran pimpinan dimaksud dalam sosialisasi dan implementasi budaya organisasi di Madrasah Aliyah al-Amiriyyah dilakukan secara tertulis dan tidak tertulis. Secara tertulis misalnya yang tertuang dalam aturan (qonun) pesantren yang terintegrasi dengan aturan (qonun) madrasah dengan lebih spesifik. Integrasi ini membuktikan adanya dukungan kuat antar pihak untuk mewujudkan lembaga pendidikan Islam berbasis pesantren yang mampu melahirkan generasi berakhlaq mulia. Sedangkan secara tidak tertulis peran yang difungsikan oleh pimpinan terkait adalah memberi keteladanan, menyampaikan dan membiasakan perilaku-perilaku mulia dalam rutinitas kegiatan pendidikan dan mendoakan peserta didik Madrasah Aliyah al-Amiriyyah agar bisa mencapai cita-cita yang diharapkan. Disinilah maka uswatun hasanah, mauidzah hasanah dan dakwatul hasanah dapat juga berintegrasi.

\section{Kesimpulan}

1. Secara sederhana budaya organisasi didefinisikan sebagai seperangkat asumsi yang dibangun dan dianut bersama oleh organisasi sebagai 
moral dalam beradaptasi dengan lingkungan eksternal dan proses integrasi internal.

2. Terdapat tiga tingkatan budaya organisasi yang berinteraksi dalam proses keorganisasian yaitu artifak; nilai-nilai; dan asumsi dasar.

3. Para pendiri suatu organisasi secara tradisional mempunyai dampak utama pada permulaan budaya organisasi, karenamereka mempunyai suatu visi mengenai bagaimana seharusnya organisasi beroperasi.

4. Budaya organisasi memiliki lima peran: (1) budaya memiliki rasa identitas dan kebanggaan, yaitu menciptakan perbedaan yang jelas antar organisasi satu dengan yang lain; (2) budaya mempermudah terbentuknya komitmen dan pemikiran yang lebih luas daripada kepentingan pribadi seseorang; (3) memperkuat strandar perilaku organisasi dalam membangun pelayanan superior pada pelanggan; (4) budaya menciptakan pola adaptasi; (5) membangun sistem kontrol organisasi secara menyeluruh.

5. Implementasi budaya organisasi adalah sebuah proses yang terintegrasi dalam sebuah simbol sosial, bisa dengan keteladanan, penokohan, pembiasaan dan lainnya

6. Budaya organisasi yang kuat dibangun oleh empat dimensi K yaitu: komitmen; kemampuan; kepaduan/kohesi; dan konsistensi.

7. Tugas inti lembaga pendidikan Islam sebagai organisasi dalam menghadapi lingkungan, baik eksternal maupun internal adalah berdaptasi

8. Budaya organisasi yang ada di Madrasah Aliyah al-Amiriyyah Blokagung dibagi menjadi tiga ranah, yaitu: (1). Budaya Keagamaan, teridiri dari; mukim di Pesantren, membaca asma'ul husna sebelum memasuki kelas, membaca doa sebelum dan sesudah pelajaran, menghafal al-Qur'an bagi peserta didik jurusan Agama, mengadakan kegiatan PHBI (Peringatan Hari Besar Islam), menggelar dan mengikuti 
festival keagamaan Islam, silaturrahim kepada Kyai/Nyai dan Ustadz/Ustadzah, melaksanakan khotmil Qur'an dan istighatsah secara rutin dan berkala, mengikuti kegiatan pesantren dan pendidikan diniyah dan ziarah ke makam para pendidiri pesantren; (2) Budaya KeIndonesiaan, terdiri dari; mengadakan upacara setiap hari senin dan hari kemerdekaan Indonesia dan mengadakan kegiatan hari-hari nasional; (3) Budaya Kemanusiaan, terdiri dari; melaksanakan kamis amal, menggelar donor darah, membantu teman dan masyarakat yang terkena musibah dan bhakti sosial kemasyarakatan.

9. Peran pimpinan dalam sosialisasi dan implementasi budaya organisasi di Madrasah Aliyah al-Amiriyyah dilakukan secara tertulis dan tidak tertulis. Secara tertulis tertuang dalam aturan (qonun) pesantren yang terintegrasi dengan aturan (qonun) madrasah dengan lebih spesifik. Sedangkan secara tidak tertulis peran yang difungsikan oleh pimpinan terkait adalah memberi keteladanan, menyampaikan dan membiasakan perilaku-perilaku mulia dalam rutinitas kegiatan pendidikan dan mendoakan peserta didiknya agar bisa mencapai cita-cita yang diharapkan, maka dengan demikian uswatun hasanah, mauidzah hasanah dan dakwatul hasanah dapat juga berintegrasi.

\section{Daftar Pustaka}

Chaitman, Jennifer A and Karen A. Jehn. 1994. Assesing The Relationship Betwee-industry Characteristic's and Organizational Culture; How You Can Be?. Academic of Management Journal 37 No.3:522-553

Espejo, Raul. 1996. Organizational Transformation and Learning: A Cybernetic Approach to Management. New York: John Wiley \& Sons

Hickman, Craig R and Michael A Silva. 1984. Creating Excellence, Managing Corporate Culture Strategy, and Change in the New Age. New York: A Plume Book 
Hofstede, Geert. 1980. Cultures and Organization, Intercultural Cooporation and its Importance for Survival: Software of the Mind, the Successful Strategist Series. London: Harper Collins Publisher

Kilmann, Ralp H. 1988. Gaining Control of the Corporate Culture. London: Jossey-Bass Publisher

Mintzberg, Henry. 1989. On Management, Inside Our Strange World of Organizations. New York: The Free Press

Poerwanto. 1992, 2004. Budaya Organisasi dan Pola Adaptasi pada Organisasi Mini Guesthouse di Kawasan Wisata Jakarta, Yogyakarta dan Bali. Penelitian. Universitas Indonesia

Robbins, Stephen P. 1998. Organizational Behavior: Concept, Controversies, Applications, edisi 8. New York: Prentice Hall

Schein, Edgar H. 1983. The Role of Founder in Creating Organizational Cultur, Organizational Dynamic, Summer. San Fransisco: Jossey-Bas Publisher

Schein, Edgar H. 1989. Organizational Culture and Leadhersip, edisi 1. San Fransisco: Jossey-Bas Publisher

Schein, Edgar. H. 1989. Organizational Culture and Leadhersip, edisi 2. San Fransisco: Jossey-Bas Publisher 